\title{
Enzymatic biodiesel production from sludge palm oil (SPO) using locally produced Candida cylindracea lipase
}

\author{
Ricca Rahman Nasaruddin, Md. Zahangir Alam and Mohammed Saedi Jami \\ Bioenvironmental Engineering Research Centre (BERC), Department of Biotechnology Engineering, \\ Faculty of Engineering International Islamic University Malaysia, P.O. Box 10, 50728 Kuala Lumpur, \\ Malaysia.
}

Accepted 28 June, 2013

\begin{abstract}
Biodiesel is a non-toxic, renewable and environmental friendly fuel. This study involved the production of biodiesel from sludge palm oil (SPO), a low-cost waste oil via enzymatic catalysis. The enzyme catalyst was a Candida cylindracea lipase, locally-produced using palm oil mill effluent as the low cost based medium. The results in solvent system for biodiesel production showed that ethanol gave higher yield of biodiesel as compared to methanol. One-factor-at-a time (OFAT) method was applied to investigate several factors for enzymatic biodiesel production. The optimum levels of ethanol-to-SPO molar ratio, enzyme loading, reaction temperature, mixing speed and reaction time were $4: 1,10 \mathrm{U}, 40^{\circ} \mathrm{C}$, $250 \mathrm{rpm}$ and $24 \mathrm{~h}$, respectively with maximum yield of biodiesel of $62.3 \%$ (w/w SPO). The SPO had a promising potential for enzymatic biodiesel production using locally-produced lipase.
\end{abstract}

Key words: Biodiesel, sludge palm oil, lipase, free fatty acid, fatty acid alkyl ester.

\section{INTRODUCTION}

Increasing energy crisis and environmental concerns by fossil fuel and its depletion reserve have led to a very intense research on sustainable and renewable sources of energy such as biodiesel (Röttig et al., 2010; Ganesan et al., 2009). Biodiesel which comprises of monoalkyl esters of long chain fatty acids has advantages as a renewable, biodegradable, clean, and non-toxic fuel (Patel et al., 2013; Moradi et al., 2013; Zheng et al., 2012; Maceiras et al., 2011; De Paola et al., 2009; Ganesan et al., 2009). Compared to fossil fuels, biodiesel produces less air pollutants, has lower sulphur content (0-24 ppm sulphur), lower aromatic content which reduces the smell of diesel exhaust and higher heat content which is about $88 \%$ of no. 2 diesel fuel (Maceiras et al., 2011; Ghaly et al., 2010; Yee and Lee, 2008).
Besides, it can be used neatly or by mixing it with diesel fuel in all conventional engines without modification (Moradi et al., 2013; Ganesan et al., 2009).

In general, the main challenge of biodiesel production is related to its feedstock and production method. The edible feedstock contributes to almost $80 \%$ of the overall cost of biodiesel production ( $\mathrm{Li}$ et al., 2012). Therefore, the use of prevalent feedstocks of biodiesel which are edible oils cause the higher price of biodiesel ( 0.70 to $1.28 \mathrm{USD} / \mathrm{L}$ ) (Yan et al., 2012). The edible oils such as sunflower, soybean, rapeseed, corn, and palm oils create competition between biodiesel and food producers thus it rises the concern on food security. The high cost of edible oils also becomes a major impulse for the search of low-cost alternative feedstock for biodiesel production.

${ }^{*}$ Corresponding author. E-mail: zahangir@iium.edu.my. Tel: +603 61964571. Fax: +603 61964442. 
Many researchers are now interested in investigating the potential of waste oils. Various waste oils have been studied such as beef tallow (Liu et al., 2011), waste cooking oil (Bezergianni et al., 2010; Knothe and Steidley, 2009; De Paola et al., 2009; Anastopoulos et al., 2009), waste animal fats (Encinar et al., 2011), and grease (Yan et al., 2012; Li et al., 2012).

Malaysia, the major player in the world palm oil industry (Idris et al., 2012; Wafti et al., 2012), generates an abundance of low cost waste oil which is sludge palm oil (SPO). Hayyan et al. (2010) reported that about 40 million tons of SPO is produced annually. The SPO is rich with free fatty acids (FFA) (40 to $80 \%$ by weight) that can be converted into biodiesel (Wafti et al., 2012). However, this property is unfavorable for common method of biodiesel synthesis, homogeneous alkalinetransesterification because the limit of FFA content for that method is $1 \%$ (Hayyan et al., 2010) or $2.5 \%$ (Ghaly et al., 2010). The catalyst can easily promote soap formation, thus reduces the yield of biodiesel and complicates the separation process (Patel et al., 2013; Ghaly et al., 2010). Acid catalyst has been used to reduce the FFA content of SPO via esterification (Hayyan et al., 2010) but this method leads to two-step processes (acid-catalyzed esterification and alkaline-catalyzed transesterification) for biodiesel production, thus consumes more energy and effort for separation process. Besides, acid catalyst is corrosive and toxic (Patel et al., 2013; Yan et al., 2012).

The above problems can be avoided using enzyme catalyst such as lipase. Lipase is biodegradable, nontoxic, contributes to ease recovery of product and glycerol and requires moderate alcohol and mild reaction conditions (Zheng et al., 2012; Yan et al., 2012; Chen et al., 2011). It can also catalyze both esterification and transesterification (Yan et al., 2012), thus it is suitable for high FFA feedstocks like SPO. However, lipase-catalyzed biodiesel production is still less attractive for commercialization because commercial lipase is very expensive (Gog et al., 2012). Also, most lipase has poor stability in organic solvent (Zheng et al., 2012; Yan et al., 2012).

Therefore, in this study, biodiesel was produced from SPO using locally produced lipase as the catalyst. The lipase was produced from Candida cylindracea using lowcost based medium, palm oil mill effluent (POME). Candida cylindracea is a well known yeast that produces industrial lipase because of its non-pathogenic characteristic and it has been recognized as (GRAS) generally regarded as safe microorganism (Salihu et al., 2011). Besides, Nuylert and Hongpattarakere (2012) also stated that lipase secreted from Candida cylindracea has exhibited biosynthetic ability and high stability.

Several factors such as type of alcohol, alcohol-to-SPO molar ratio, enzyme loading, reaction temperature, mixing speed and reaction time that influence the enzymatic biodiesel production from SPO were investigated to increase the yield of biodiesel. This novel research can add in more information on the application of low-cost waste oil, SPO, especially in the enzymatic biodiesel production using low-cost locally-produced lipase. Furthermore, the enzymatic biodiesel production from SPO using the locally-produced POME based lipase would be competitive to the high cost of current practice of biodiesel feedstock and the environmental concern of these wastes disposal.

\section{MATERIALS AND METHODS}

\section{Raw materials and chemicals}

SPO was obtained from West Oil Mill of Sime Darby Plantation at Carey Island, Selangor, Malaysia. It was preserved in cold room at $4^{\circ} \mathrm{C}$ to avoid any decomposition, oxidation and changes of the FFA content. The locally-produced Candida cylindracea lipase was a contribution of an established research of Bioenvironmental Engineering Research Centre, International Islamic University Malaysia. The lipase production was done according to the methods of Salihu et al. (2011). All the chemicals such as organic solvents and reagents of laboratory and analytical grades with various brands (Merck, Sigma Aldrich, Supelco, Dr. Ehrenstorfer, HmBG, PC Laboratory, System and Bendosen) were purchased from local suppliers (Merck Sdn. Bhd, Teras Medik Sdn. Bhd and IT-Tech Research (M) Sdn. Bhd.)

\section{Preparation and characterization of SPO}

Prior to use, SPO was preheated at $60^{\circ} \mathrm{C}$ until it became homogeneous. The characteristics of the SPO such as acid and saponification values and FFA and moisture contents were determined according to Malaysian Palm Oil Board (MPOB) test methods (Ainie et al., 2005). The fatty acids composition of the SPO were analyzed using GC/FID (Perkin Elmer Clarus 500), splitsplitless mode of injector, isotherm oven at $250^{\circ} \mathrm{C}$ using non-polar stationery phase BPX70 capillary column.

\section{Production of lipase}

The lipase production method was based on the study of Salihu et al. (2011). The yeast, C. cylindracea, ATCC 14830 was obtained from American Type culture collection while POME was obtained from West Oil Mill of Sime Darby Plantation at Carey Island, Selangor, Malaysia. The strain was grown on potato dextrose agar plates at $28^{\circ} \mathrm{C}$ for 4 days and sub-cultured every two weeks. It was maintained and preserved at $4^{\circ} \mathrm{C}$. The PDA-plated culture of $C$. cylindracea was suspended in $10 \mathrm{~mL}$ of sterile distilled water and 1 $\mathrm{mL}$ of the suspension was used as the inoculums for pre-cultures. Lipase was produced in POME at $1 \%$ total suspended solid (TSS) as the basal medium containing nutrients $(0.45 \% \mathrm{v} / \mathrm{v}$ peptone, and $0.65 \% \mathrm{v} / \mathrm{v}$ Tween-80) and $2.2 \%(\mathrm{v} / \mathrm{v})$ inoculums. The initial $\mathrm{pH}$ was adjusted to $\mathrm{pH} 6.0$ using $1 \mathrm{M} \mathrm{NaOH}$. The flasks were incubated for 6 days at $28^{\circ} \mathrm{C}$ under orbital shaking at $150 \mathrm{rpm}$. The cell-free filtrate was used as a source of extracellular lipase.

\section{Lipase activity and protein assays}

Lipase activity was assayed according to spectrophotometric assay method reported by Gopinath et al. (2005) with a few modifications. The phosphate buffer in that method was replaced by phosphate- 
Table 1. Fatty acids composition of SPO in this study.

\begin{tabular}{lcc}
\hline Fatty acid & Structure & Composition (\%) \\
\hline Capric acid & C10:0 & $0.04 \pm 0.05$ \\
Lauric acid & C12:0 & $0.62 \pm 0.82$ \\
Myristic acid & C14:0 & $1.25 \pm 0.24$ \\
Palmitic acid & C 16:0 & $42.12 \pm 1.02$ \\
Palmitoleic acid & C16:1 & $0.15 \pm 0.02$ \\
Stearic acid & C18:0 & $4.26 \pm 0.07$ \\
Oleic acid & C18:1 & $40.31 \pm 1.03$ \\
Linoleic acid & C18:2 & $10.49 \pm 0.81$ \\
Alpha-Linoleic acid & C18:3 & $0.26 \pm 0.16$ \\
Arachidic acid & C20:0 & $0.43 \pm 0.44$ \\
\hline
\end{tabular}

Table 2. Chemical properties of SPO in this study.

\begin{tabular}{lc}
\hline Chemical Properties & Value \\
\hline FFA $(\%$ as palmitic acid) & $51.64 \pm 0.59$ \\
Acid value (mg KOH/mg) & $113.17 \pm 1.29$ \\
Saponification value $(\mathrm{mg} \mathrm{KOH} / \mathrm{g})$ & $191.92 \pm 2.88$ \\
Moisture Content $(\%)$ & $1.00 \pm 0.04$ \\
\hline
\end{tabular}

citrate buffer because the $\mathrm{pH}$ of the buffer can be varied from 2.0 to 9.0. The phosphate-citrate buffer was prepared according to the study of Pearse (1980). 4-Nitrophenyl palmitate (pNPP) was used as substrate. First, $10 \mathrm{~mL}$ isopropanol containing $30 \mathrm{mg}$ pNPP was mixed with $9 \mathrm{~mL}$ phosphate-citrate buffer. A total amount of $2.4 \mathrm{~mL}$ freshly prepared substrate solution was mixed with three different volume of enzyme solution (2, 4 and $6 \mu \mathrm{l}$ ) and then incubated at $37^{\circ} \mathrm{C}$. After $30 \mathrm{~min}$ of incubation, absorbance at $410 \mathrm{~nm}$ was measured against an enzyme-free control. One enzyme unit was defined as $1 \mu \mathrm{mol}$ of 4-nitrophenol enzymatically released from the substrate in milliliters per minute $(\mathrm{mL} / \mathrm{min})$. Lipase concentration was determined using common method of protein assay which was universal Bradford method where bovine serum albumin was used as the standard. The lipase with known activity and concentration was prepared in aliquots of $40 \mathrm{~mL}$ and preserved in freezer $\left(-20^{\circ} \mathrm{C}\right)$ to avoid rapid reduction of its activity.

\section{Enzymatic biodiesel production from SPO}

All experiments were done in a batch mode and free enzyme system in $250 \mathrm{~mL}$ screw-capped flask. A $25 \mathrm{~g}$ of SPO was added to the flask with $4: 1$ alcohol-to-SPO molar ratio and 1:10 lipase-to SPO volume ratio. The mixture was then incubated in incubation shaker at $40^{\circ} \mathrm{C}$ and $200 \mathrm{rpm}$ agitation speed for $5 \mathrm{~h}$. At the end of the reaction, the mixture was centrifuged to remove the lipase before separating the product in separating funnel. The product was washed with recently boiled distilled water to remove glycerol, excess alcohol and remaining lipase. The upper liquid as biodiesel in the separating funnel was recovered and dried in oven to remove the remaining water and alcohol. The product was analyzed using $\mathrm{GC} / \mathrm{MS}$ and the yield was measured.

\section{Investigation and optimization of influential factors}

The investigation and optimization of influential factors of enzymatic biodiesel production from SPO was done using OFAT method. First, two different alcohols (methanol and ethanol) were studied.
The selected alcohol was then used for the investigation of optimum alcohol-to-SPO molar ratio $(2: 1,3: 1,4: 1,6: 1,6: 1$, and $8: 1)$, enzyme loading $(5,10,30,50,70$ and $100 \mathrm{U})$, reaction temperature $\left(30,40,50\right.$ and $\left.60^{\circ} \mathrm{C}\right)$, mixing speed $(100,150,200$, $250,300,350$ and $400 \mathrm{rpm})$ and reaction time $(5,12,24,36,48,60$ and $72 \mathrm{~h})$.

\section{Analytical analysis}

The presence of esters in biodiesel was identified using GC/MS (Agilent Technologies 7890A gas chromatography equipped with 5975C mass spectrometer). The GC/MS was operated with splitsplitless mode of injection; the capillary column was DB-wax with a length of $30 \mathrm{~m}$, film thickness of $0.25 \mu \mathrm{m}$ and internal diameter of $0.25 \mathrm{~mm}$. Helium was used as carrier gas with a flow rate of 30 $\mathrm{mL} / \mathrm{min}$, measured at $50^{\circ} \mathrm{C}$; the run time was $35 \mathrm{~min}$. The temperature of the injector and detector were 250 and $280^{\circ} \mathrm{C}$ respectively. $15 \mathrm{mg}$ sample of biodiesel was measured in GC vial. The sample was diluted with $n$-hexane (AR Grade) to $1 \mathrm{~mL}$ final volume prior to injection into GC/MS. The yield of biodiesel is defined as the weight percentage of final product relative to the weight of SPO at the beginning of the experiment.

\section{RESULTS AND DISCUSSION}

\section{Characteristics of SPO}

Fatty acids composition determines the type of esters in biodiesel (Ruan et al., 2012). In this study, the fatty acids composition of SPO analyzed by GC/FID is shown in Table 1. Based on the results, it can be seen that the highest amount of fatty acids in SPO is palmitic acid with $42.12 \pm 1.02 \%$, followed by oleic acid with $40.31 \pm 1.03 \%$ and linoleic acid with $10.49 \pm 0.81 \%$. Hayyan et al. (2010) and Chow and Ho (2002) also reported that palmitic acid is the most abundant fatty acid in SPO with $42.84 \%$ and $51 \%$ respectively.

Table 2 illustrates some chemical properties of SPO used in this study. Among all properties, acid and saponification values and FFA and moisture contents are the most important for the biodiesel production. According to the results, it was found that the FFA content of SPO was too high (51.64 $\pm 0.59 \%)$, thus it is unfavourable for the alkaline-catalyzed transesterification. The moisture content of SPO was $1.00 \pm 0.04 \%$. Water is the critical factor in enzymatic biodiesel production because it promotes the reversible reaction of esterification. Low moisture content of SPO is favourable especially when free lipase system was used for the locally-produced lipase which its solution was already has high amount of water. The saponification value of 191.92 $\mathrm{mg} \mathrm{KOH} / \mathrm{g}$ oil gave the average molecular weight of 877 $\mathrm{g} / \mathrm{mol}$.

\section{Characteristics of locally-produced lipase}

The lipase activity is highly dependent on the $\mathrm{pH}$ of the reaction mixture. Figure 1 shows the lipase activity at 


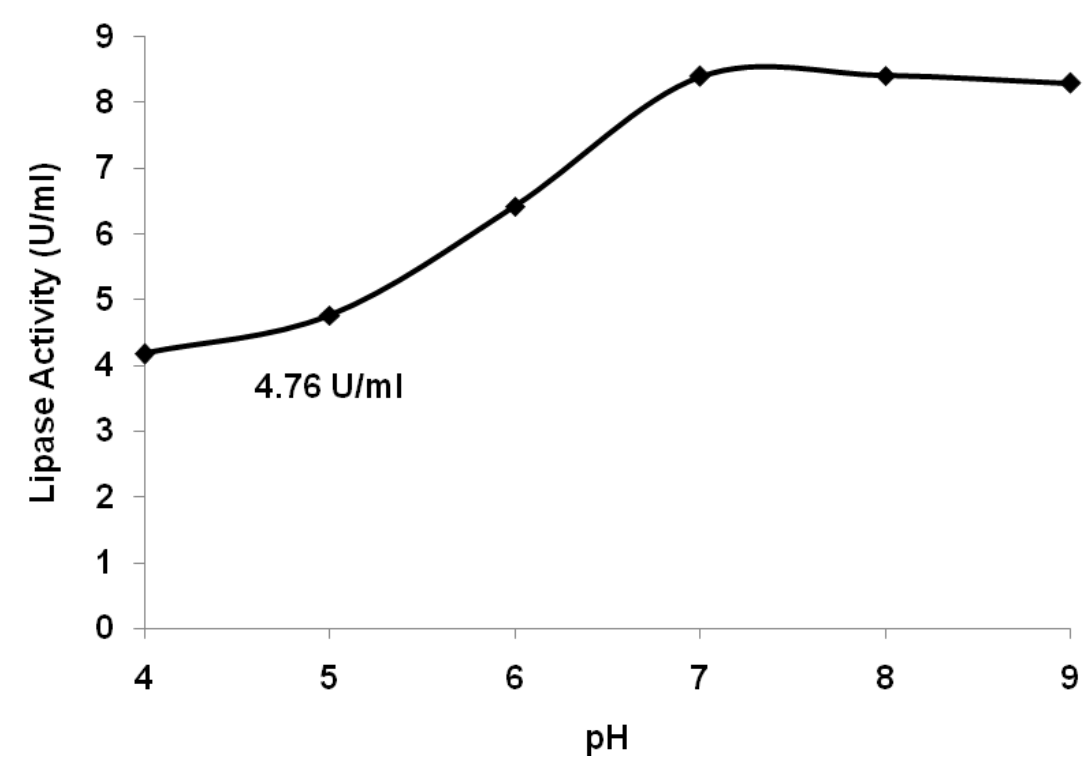

Figure 1. Lipase activity $(\mathrm{U} / \mathrm{ml})$ at different $\mathrm{pH}$.

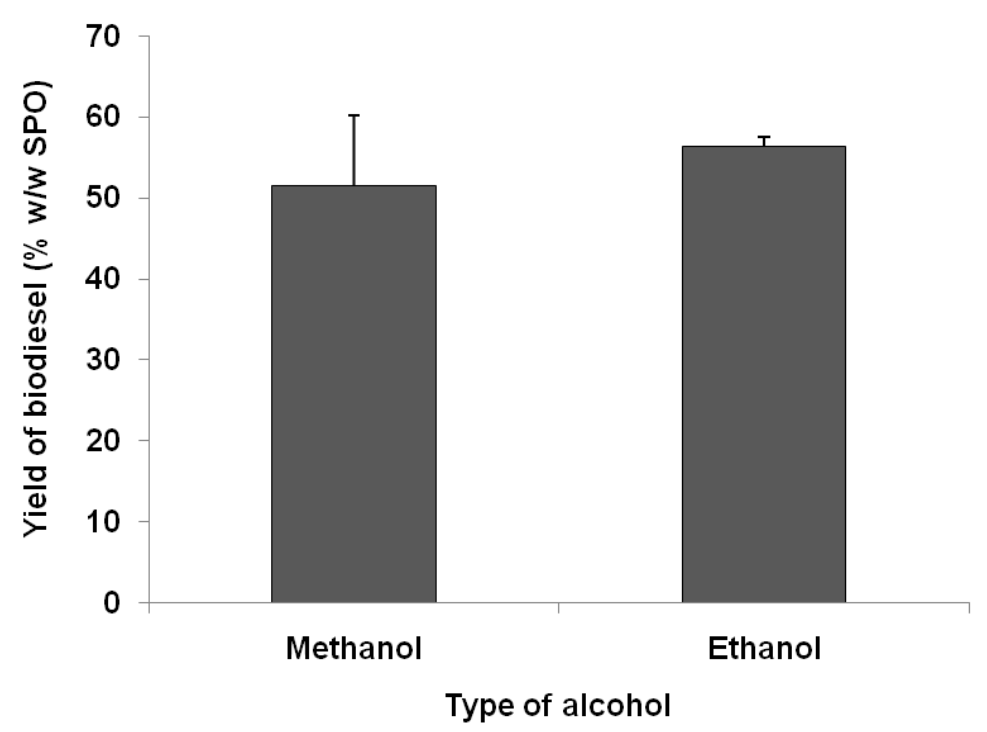

Figure 2. Effect of methanol and ethanol on biodiesel production from sludge palm oil (SPO) using locally produced Candida cylindracea lipase.

different $\mathrm{pH}$. It can be seen from the result that the locally-produced lipase was an optimum activity at $\mathrm{pH} 7.0$ to 8.0 similar with most lipases (Sivaramakrishnan and Muthukumar, 2012). However, the average $\mathrm{pH}$ of the reaction mixture containing SPO and alcohol was $5.0 \pm$ 0.5 . The activity of the lipase significantly decreases when the $\mathrm{pH}$ is less than $\mathrm{pH}$ 7.0. Unfortunately, the $\mathrm{pH}$ adjustment in the non-aqueous SPO and alcohol mixture is nearly impossible because the addition of any alkaline or base caused the soap formation. Thus, the lipase activity was taken at $\mathrm{pH} 5.0$ which was $4.76 \mathrm{U} / \mathrm{ml}$. The concentration of the lipase used in this study was 0.15 $\mathrm{mg} / \mathrm{ml}$.

\section{Effect of methanol and ethanol}

Short-chain alcohols are usually used as the acylacceptor in biodiesel synthesis. The effects of methanol and ethanol are illustrated in Figure 2. Based on the results, it was found that the ethanol gave higher yield of biodiesel $(56.5 \% \mathrm{w} / \mathrm{w}$ SPO) than the methanol $(51.6 \%$ 


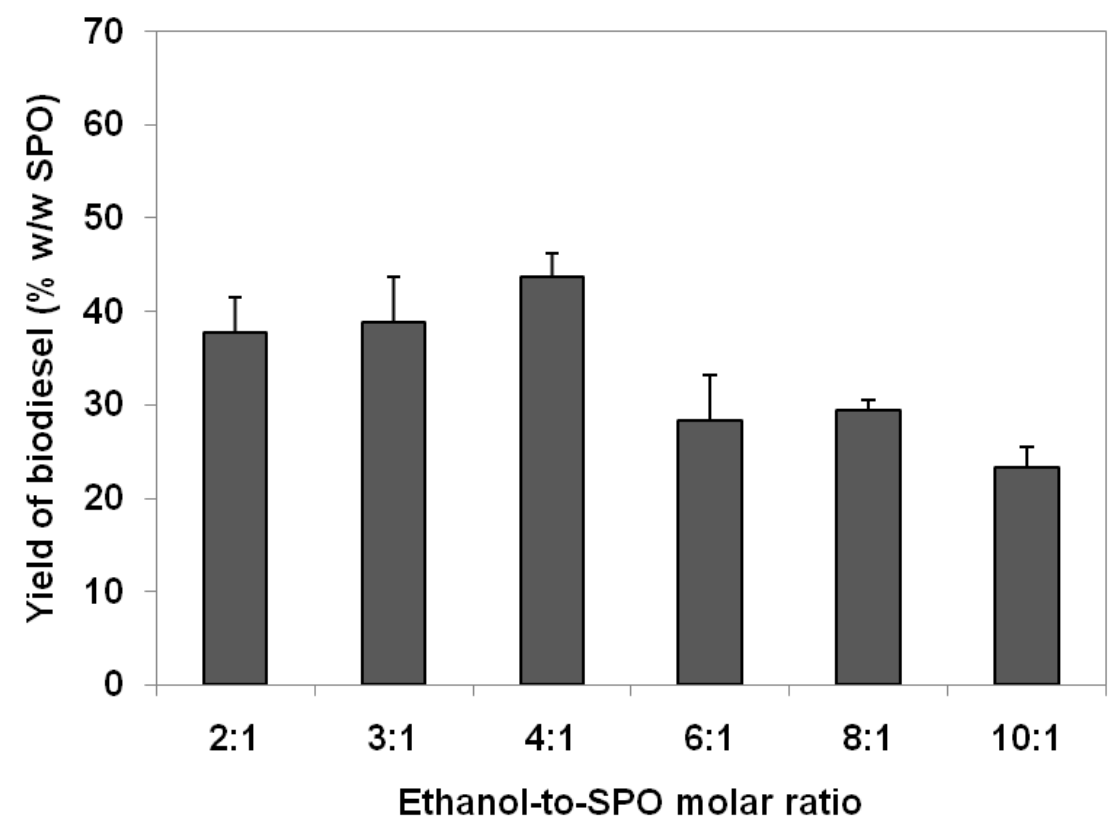

Figure 3. Effect of ethanol-to-SPO molar ratio on biodiesel production from sludge palm oil (SPO) using locally produced Candida cylindracea lipase.

$w / w$ SPO). Although, the difference between the yield of ethanol and methanol was small, but in terms of cost and economic benefit, ethanol can be more attractive as compared to methanol because ethanol can now be produced from the renewable and low cost agricultural biomass (Ghaly et al., 2010). Thus, ethanol biodiesel appears as a $100 \%$-renewable alternative (Rosa et al., 2009). Besides, methanol is a polar solvent which can trip water molecules from the enzyme surface thus affecting its native conformation and reduces its activity (Sivaramakrisnan and Muthukumar, 2012). Ethanol was found to give less inhibition effect to the activity of lipase because it is less hydrophilic than methanol. Nuylert and Hongpattarakere (2012) also stated that most lipases studied so far including the lipase secreted by $C$. cylindracea were very sensitive to methanol.

\section{Effect of ethanol-to-SPO molar ratio}

Ethanol solvent system was used for further investigations. The effect of ethanol-to-SPO molar ratio is illustrated in Figure 3. Based on the results, it was found that the maximum yield of biodiesel $(43.8 \% \mathrm{w} / \mathrm{w}$ SPO) was achieved at 4:1 ethanol-to-SPO molar ratio. Even though, the stoichiometry requires only 3 moles of alcohol to convert $1 \mathrm{~mol}$ of triacylglyceride into 3 moles of esters, however the transesterification reaction is a reversible or an equilibrium-limited reaction (Röttig et al., 2010; Patel et al., 2013). Therefore, excess alcohol is used to favor the forward reaction which produces more esters (Patel et al., 2013). Similarly, the esterification is also a reversible or an equilibrium-limited reaction. More alcohol is needed to shift the reaction forward. Unless the high amount of water (by-product of esterification) will cause the reversible reaction, thus lowering the yield of biodiesel.

However, too excessive alcohol can cause the conformational change of the lipase protein structure thus inhibits its activity and reduces the yield of biodiesel. This effect can be seen when the ethanol-to-SPO molar ratio increased to $6: 1$. Therefore, $4: 1$ was the optimum ethanol-to-SPO molar ratio for the enzymatic biodiesel production from SPO. The optimum level of $4: 1$ alcoholto-oil molar ratio was also reported by $\mathrm{Li}$ et al. (2012). The moderate amount of alcohol is favorable in biodiesel production because it reduces the cost of raw materials and effort for removing the excess alcohol.

\section{Effect of enzyme loading}

Enzyme loading is the limiting factor for the water content in this enzymatic biodiesel production because the lipase solution was in liquid form. Whenever, the enzyme loading increases, the water content also increases. Higher amount of enzyme is favourable for the biodiesel synthesis but the higher amount of water is unfavourable for the biodiesel synthesis. The variation of enzyme loading and water content are shown in Table 3.

The effect of enzyme loading in this study is illustrated in Figure 4. Based on the results, it was found that the 
Table 3. Variation of enzyme loading and water content.

\begin{tabular}{ccc}
\hline $\begin{array}{c}\text { Enzyme loading } \\
(\mathbf{U})\end{array}$ & $\begin{array}{c}\text { Water volume } \\
(\mathbf{m L})\end{array}$ & $\begin{array}{c}\text { Water content } \\
(\% \text { in SPO) }\end{array}$ \\
\hline 5 & 1.050 & 3.4 \\
10 & 2.100 & 6.5 \\
30 & 6.299 & 17.4 \\
50 & 10.498 & 25.9 \\
70 & 14.697 & 32.9 \\
100 & 20.995 & 41.2 \\
\hline
\end{tabular}

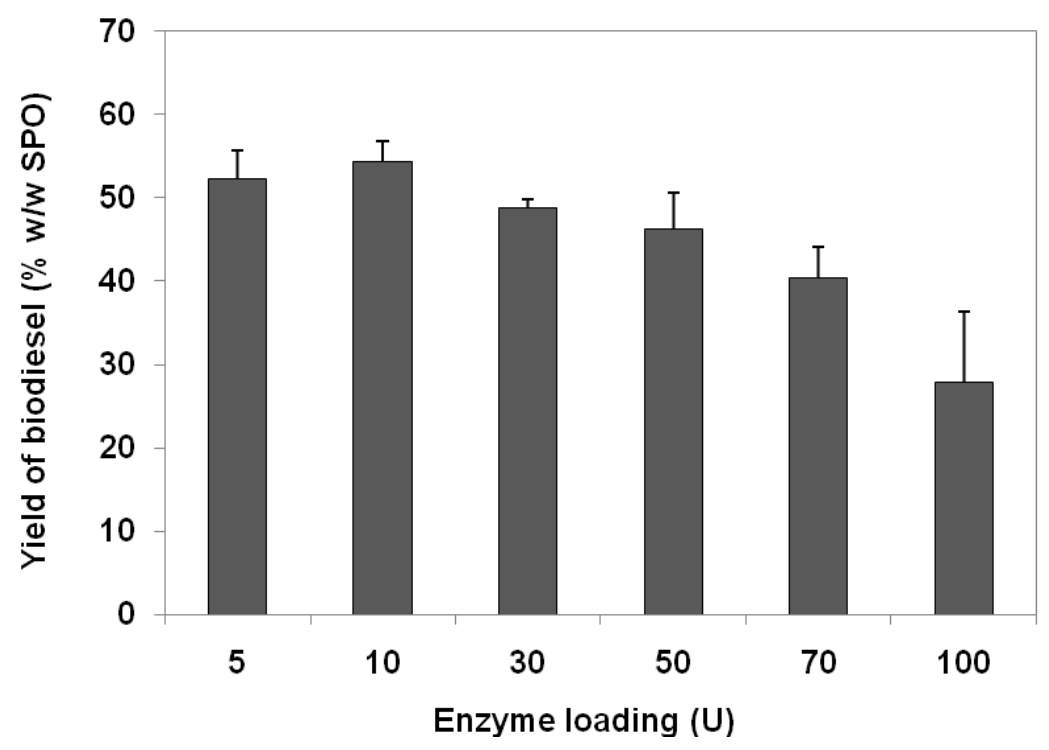

Figure 4. Effect of enzyme loading on biodiesel production from sludge palm oil (SPO) using locally produced Candida cylindracea lipase.

highest yield of biodiesel (54.4\% w/w SPO) was achieved at $10 \mathrm{U}$. The decreasing of biodiesel yield when enzyme loading is more than $10 \mathrm{U}$ might be due to the excess amount of water that promotes reversible esterification reaction (Patel et al., 2013). All the FFA might not be fully converted into biodiesel within the $5 \mathrm{~h}$ reaction and remained in the product. The remaining non-converted FFA was solidified and was removed at the end of biodiesel separation process, thus gave the lower yield of biodiesel. Besides, the excessive amount of water also affects the transesterification of TAG to be slower because of the competition between the alcohol and water molecules in the catalytic site of the lipase (Patel et al., 2013).

\section{Effect of reaction temperature}

Reaction temperature is very important for enzymatic biodiesel production. Lipase activity is significantly dependent on the reaction temperature. In general, for the $10^{\circ} \mathrm{C}$ increment of temperature, enzyme activity can increase up to 50 to $100 \%$ until it reaches the optimum temperature. In this study, the effect of reaction temperature is shown in Figure 5. Accordingly, the results show that the highest yield of biodiesel $(51.8 \% \mathrm{w} / \mathrm{w}$ SPO) was achieved at optimum temperature of $40^{\circ} \mathrm{C}$. This optimum reaction temperature is within the range of optimum temperature $\left(30\right.$ to $\left.40^{\circ} \mathrm{C}\right)$ of $C$. cylindracea lipase that was reported by Park et al. (2008). Further increasing the temperature caused the reduction in the yield of biodiesel because enzymes are protein and they become denatured when heated beyond their optimum temperature (Sivaramakrishnan and Muthukumar, 2012). Besides, the rate of reaction of lipase in enzymatic biodiesel production from SPO was higher at higher reaction temperature because at higher temperature, SPO can melt homogenously and has lower viscosity, thus allowing higher diffusion rate of substrate into the lipase's active site. Meanwhile, at lower temperature, the 


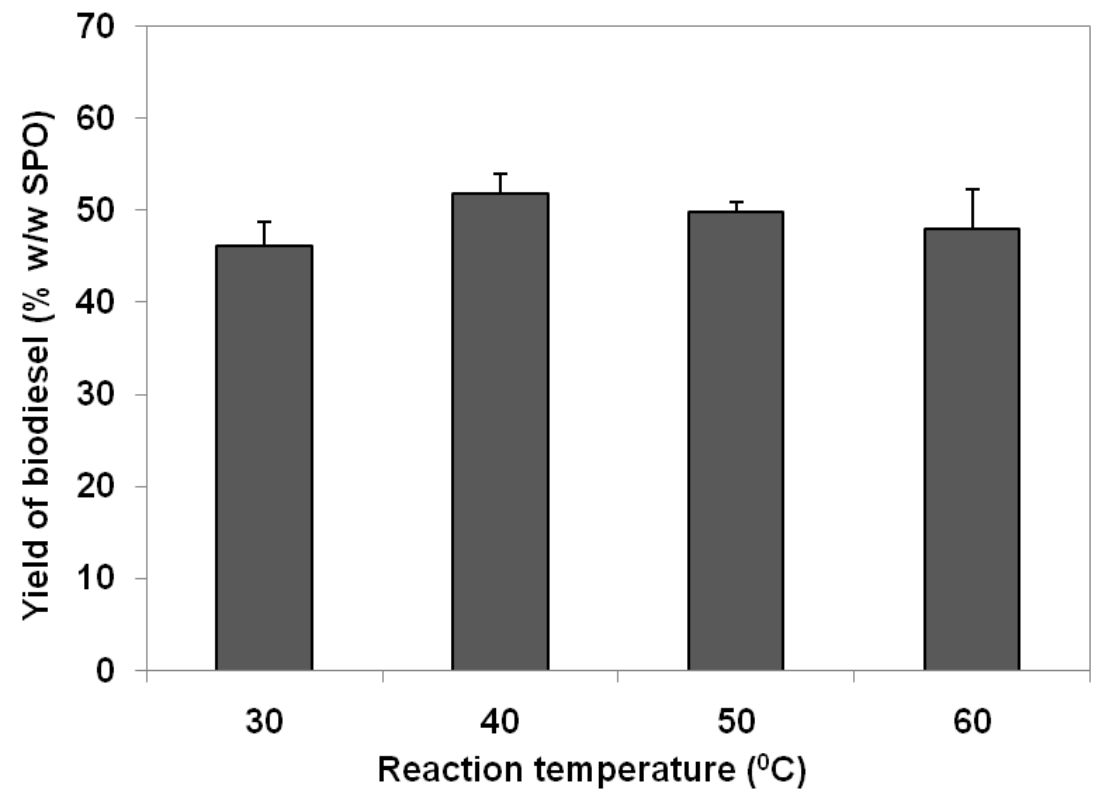

Figure 5. Effect of reaction temperature on biodiesel production from sludge palm oil (SPO) using locally produced Candida cylindracea lipase.

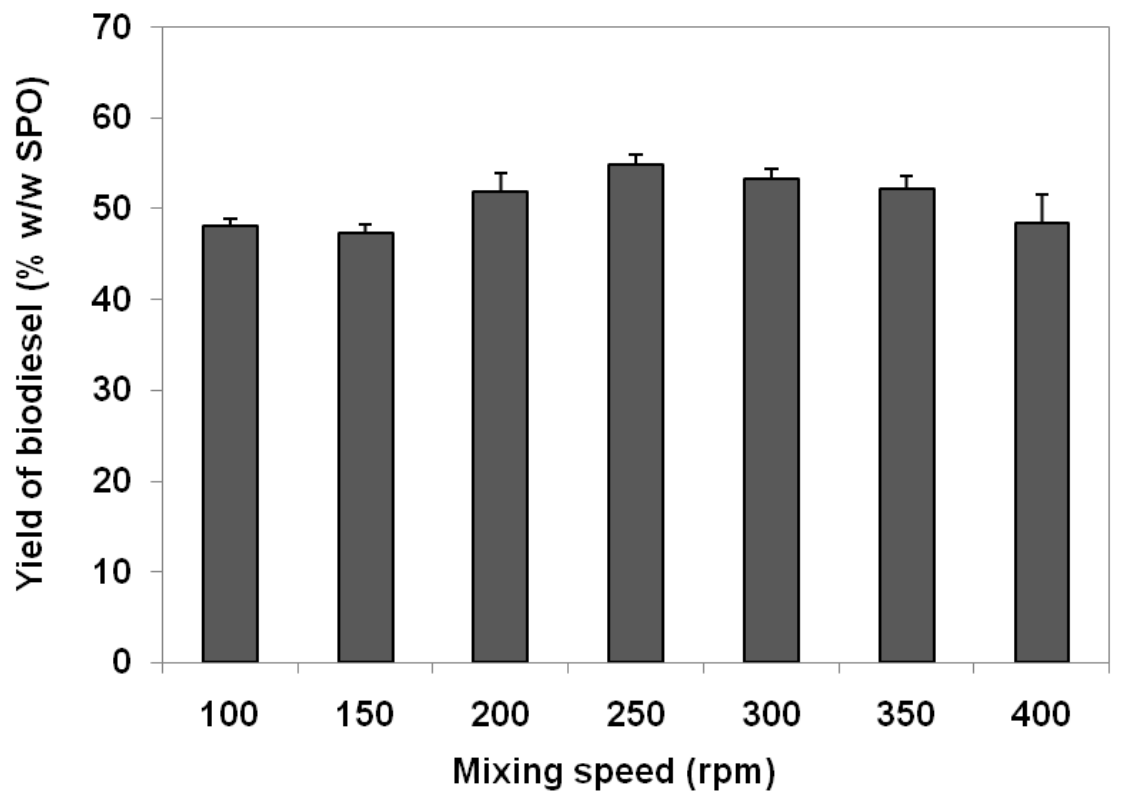

Figure 6. Effect of mixing speed on biodiesel production from sludge palm oil (SPO) using locally produced Candida cylindracea lipase.

viscosity of SPO was higher, thus causing poor diffusion between the phases and slower reaction rate.

\section{Effect of mixing speed}

Mixing is another important factor for the enzymatic biodiesel production because the activity of lipase can only occur at the water-oil interface. Mixing can generate more water-oil interfaces so that more lipase can react on oil for enzymatic transesterification and esterification. The effect of mixing speed is illustrated in Figure 6. Based on the results, it was found that the highest yield of biodiesel $(54.9 \% \mathrm{w} / \mathrm{w} \mathrm{SPO})$ was achieved at the optimum mixing 


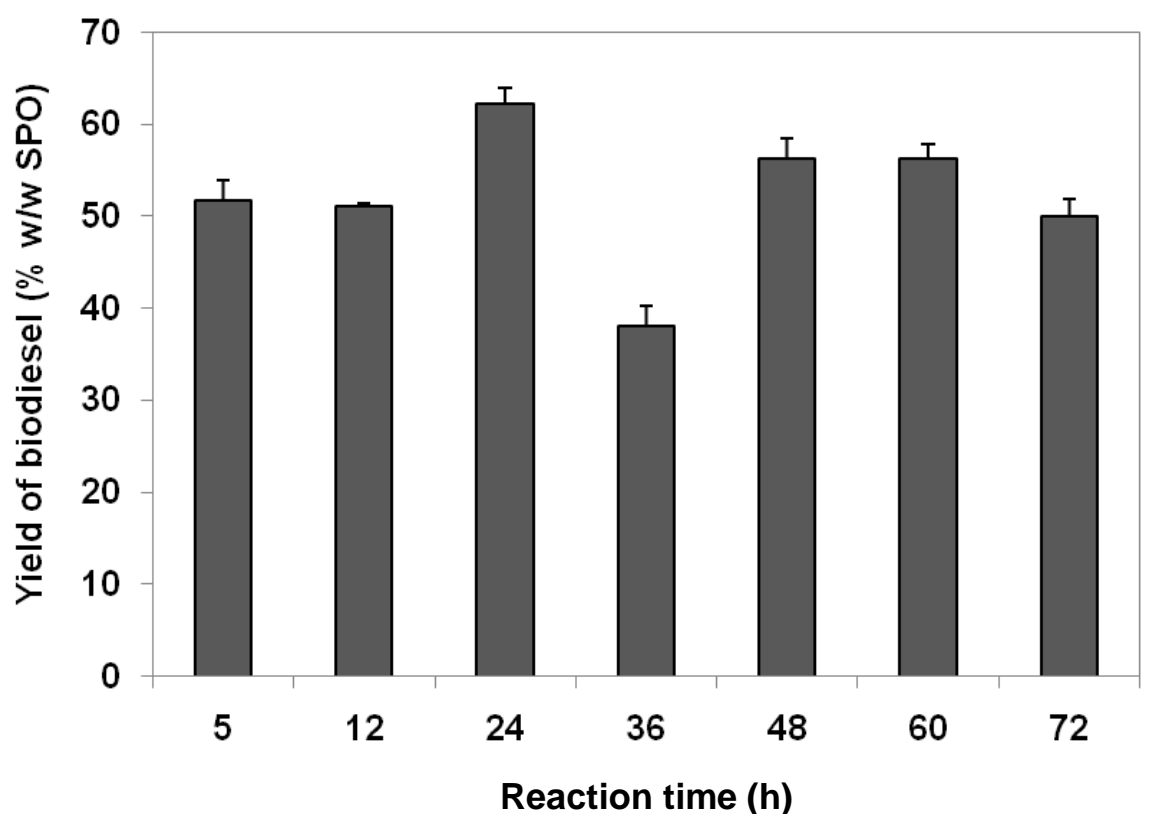

Figure 7. Effect of reaction time on biodiesel production from sludge palm oil (SPO) using locally produced Candida cylindracea lipase.

speed of $250 \mathrm{rpm}$. Although higher mixing speed can increase the contact between the substrate and the catalytic site of lipase, but too high of mixing speed can destroy the structure of enzyme (Jung et al., 2010). Meanwhile, lowering the mixing speed can significantly reduces the contact surface between the enzyme and the substrate due to the enzyme clustering thus gave lower reaction rate (De Paola et al., 2009).

\section{Effect of reaction time}

In general, the reaction time for the enzymatic biodiesel production is always longer than the biodiesel production using chemical catalyst. The reason might be due to the moderate alcohol-to- oil molar ratio, temperature and mixing speed that cause the forward reaction of transesterification and esterification to be slower. In this study, the effect of reaction time is shown in Figure 7. Based on the results, it was found that the highest yield of biodiesel $(62.3 \% \mathrm{w} / \mathrm{w}$ SPO) was achieved at the optimum reaction time of $24 \mathrm{~h}$. Mander et al. (2012) also reported that the $24 \mathrm{~h}$ is the optimum reaction time of enzymatic biodiesel production from olive oil using nonimmobilized Streptomyces sp. CS268 lipase. Shorter reaction times were found to be not adequate to establish the kinetics of the enzyme activity due to the partially reversible character of the ethanolysis process (Verdugo et al., 2010). Meanwhile, longer reaction time leads to the reduction of end product (biodiesel) due to the reversible reaction (hydrolysis) thus resulting in the loss of esters
(Mathiyazhagan and Ganapathi, 2011).

\section{Conclusions}

The present study shows that different alcohol, alcoholto-oil molar ratio, enzyme loading, reaction temperature, mixing speed and reaction time are influential factors for enzymatic biodiesel production from SPO. At this stage, the highest yield of biodiesel was $62.3 \% \mathrm{w} / \mathrm{w}$ SPO with the optimum conditions (4:1 ethanol-to-SPO molar ratio, $40^{\circ} \mathrm{C}$ temperature, $250 \mathrm{rpm}$ mixing speed, and 24 hours reaction time). However, the yield of biodiesel can be further improved by immobilizing the lipase thus reducing the amount of water that affect the reversible reaction significantly. The utilization of SPO and the locally produced POME based lipase shows a promising potential to reduce the cost of biodiesel production and to reduce the environmental pollutions that are caused by these palm-oil industrial wastes.

\section{ACKNOWLEDGEMENT}

The authors would like to thank the personnel of Sime Darby Research Sdn. Bhd. for supplying the SPO. Highest appreciation was also given to the Department of Biotechnology Engineering, International Islamic University Malaysia (IIUM) for providing the facilities to undertake this research. This research was funded by the Ministry of Higher Education using Exploratory Research 


\section{Grant Scheme (ERGS-11-002-0002).}

\section{REFERENCES}

Ainie K, Siew WL, Tan YA, Nor Aini I, Mohtar Y, Tang TS, Nuzul Al (2005). MPOB Test Methods. Malaysia: Malaysian Palm Oil Board.

Anastopoulos G, Zannikou Y, Stournas S, Kalligeros S (2009). Transesterification of Vegetable Oils with Ethanol and Characterization of the Key Fuel properties of Ethyl Esters. Energies 2:362-376.

Bezergianni S, Dimitriadis A, Kalogianni A, Pilavachi PA (2010). Hydrotreating of waste cooking oil for biodiesel production. Part I: Effect of temperature on product yields and heteroatom removal. Bioresour. Technol. 101: 6651-6656.

Chen H, Ju H, Wu T, Liu Y, Lee C, Chang C, Chung Y, Shieh C (2011). Continuous Production of Lipase-Catalyzed Biodiesel in a PackedBed Reactor: Optimization and Enzyme Reuse Study. J. Biomed. Biotechnol. 1-6.

Chow MC, Ho CC (2002). Chemical Composition Of Oil Droplets From Palm Oil Mill Sludge. J. Oil Palm Res. 14(1): 25-34.

De Paola MG, Ricca E, Calabrò V, Curcio S, lorio G (2009). Factor analysis of transesterification reaction of waste oil for biodiesel production. Bioresour. Technol. 100: 5126-5131.

Encinar JM, Sánchez N, Martínez G, García L (2011). Study of biodiesel production from animal fats with high free fatty acid content. Bioresour. Technol. 102:10907-10914.

Ganesan D, Rajendran A, Thangavelu V (2009). An overview on the recent advances in the transesterification of vegetable oils for biodiesel production using chemical and biocatalysts. Rev. Environ. Sci. Biotechnol. 8: 367-394.

Ghaly AE, Dave D, Brooks MS, Budge S (2010). Production of Biodiesel by Enzymatic Transesterification: Review. Am. J. Biochem. Biotechnol. 6(2): 54-76.

Gog A, Roman M, Tos M, Paizs C, Irimies DF (2012). Biodiesel production using enzymatic transesterification: Current state and perspectives. Renew. Energy 39: 10-16.

Gopinath SCB, Anbu P, Hilda A (2005). Extracellular enzymatic activity profiles in fungi isolated from oil-rich environments. Mycoscience 46: 119-126.

Hayyan A, Alam MZ, Kabbashi NA, Mirghani MES, Hakimi NINM, Siran YM, Tahiruddin S (2010). Sludge palm oil as a renewable raw material for biodiesel production by two-step processes. Bioresour. Technol. 101: 7804-7811.

Idris SS, Rahman AN, Ismail K (2012). Combustion characteristics of Malaysian oil palm biomass, sub-bituminous coal and their respective blends via thermogravimetric analysis ( TGA ). Bioresour. Technol. 123: 581-591.

Jung S-M, Park Y-C, Park K (2010). Effects of Enviromental Conditions and Methanol Feeding Strategy on Lipase-mediated Biodiesel Production Using Soybean Oil. Biotechnol. Bioproc. E. 15: 614-619.

Knothe G, Steidley KR (2009). A comparison of used cooking oils: A very heterogeneous feedstock for biodiesel. Bioresour. Technol. 100: 5796-5801.

Li A, Ngo TPN, Yan J, Tian K, Li Z. (2012). Whole-cell based solventfree system for one-pot production of biodiesel from waste grease. Bioresour. Technol. 114: 725-729.

Liu S, Wang Y, Oh J-H, Herring JL (2011). Fast biodiesel production from beef tallow with radio frequency heating. Renew. Energy 36: 1003-1007.

Maceiras R, Vega M, Costa C, Ramos P, Márquez MC (2011). Enzyme deactivation during biodiesel production. Chem. Eng. J. 166: 358361.

Mander P, Cho SS, Simkhada JR, Choi YH, Park DJ, Ha JW, Yoo JC (2012). An Organic Solvent-tolerant Alkaline Lipase from Streptomyces sp. CS268 and Its Application in Biodiesel Production. Biotechnol. Bioproc. E. 17: 67-75.
Mathiyazhagan M, Ganapathi A (2011). Factors Affecting Biodiesel Production. Res. Plant Biol. 1(2): 1-5.

Moradi G R, Dehghani S, Khosravian F, Arjmandzadeh A (2013). The optimized operational conditions for biodiesel production from soybean oil and application of artificial neural networks for estimation of the biodiesel yield. Renew. Energy 50: 915-920.

Nuylert A, Hongpattarakere T (2012). Improvement of cell-bound lipase from Rhodotorula mucilaginosa P11l89 for use as a methanoltolerant, whole-cell biocatalyst for production of palm-oil biodiesel. Ann. Microbiol.

Park EY, Sato M, Kojima S (2008). Lipase-catalyzed biodiesel production from waste activated bleaching earth as raw material in a pilot plant. Bioresour. Technol. 99: 3130-3135.

Patel A, Brahmkhatri V, Singh N (2013). Biodiesel production by esterification of free fatty acid over sulfated zirconia. Renew. Energy 51: 227-233.

Pearse AGE (1980). Histochemistry. Theoretical and Applied. Vol. 1. Preparative and optical technology. Edinburgh: Churchill Livingstone.

Rosa CD, Morandim MB, Ninow JL, Oliveira D, Treichel H, Oliveira JV (2009). Continuous lipase-catalyzed production of fatty acid ethyl esters from soybean oil in compressed fluids. Bioresour. Technol. 100: 5818-5826.

Röttig A, Wenning L, Broker D, Steinbüchel A (2010). Fatty acid alkyl esters: perspectives for production of alternative biofuels. Appl. Microbiol. Biotechnol. 85: 1713-1733

Ruan C, Xing W, Teixeira da Silva JA (2012). Potential of five plants growing on unproductive agricultural lands as biodiesel resources. Renew. Energy .41: 191-199.

Salihu A, Alam MZ, AbdulKarim MI, Salleh HM (2011). Optimization of lipase production by Candidda cylindracea in palm oil mill effluent based medium using statistical experimental design. J. Mol. Catal. B: Enzyme 69: 66-73.

Sivaramakrishnan R, Muthukumar K (2012). Isolation of Thermo-stable and Solvent-Tolerant Bacillus $s p$. Lipase for the Production of Biodiesel. Appl. Biochem. Biotechnol. 166: 1095-1111.

Verdugo C, Luque R, Luna D, Hidalgo JM, Posadillo A, Sancho ED, Rodriguez S (2010). A comprehensive study of reaction parameters in the enzymatic production of novel biofuels integrating glycerol into their composition. Bioresour. Technol.101: 6657-6662.

Wafti NA, Harrison LLN, Choo YM (2012). Value-added Products from Palm Sludge Oil. Journal of Applied Sciences. 12(11): 1199-1202.

Yan J, Li A, Xu Y, Ngo TPN, Phua S, Li Z (2012). Efficient production of biodiesel from waste grease: One-pot esterification and transesterification with tandem lipases. Bioresour. Technol. 123: 332-337.

Yee KF, Lee KT (2008). Palm oil as feedstocks for biodiesel production via heterogenous transesterification: Optimization study. International Conference on Enviornment (ICENV 2008).

Zheng J, Xu L, Liu Y, Zhang X, Yan Y (2012). Lipase-coated $\mathrm{K}_{2} \mathrm{SO}_{4}$ micro-crystals: Preparation, characterization, and application in biodiesel production using various oil feedstocks. Bioresour. Technol. 110: 224-231. 